\title{
Mozingo Studies I. Ice phenology and limnological legacies in a mid-continental reservoir
}

\author{
Kurt A. HABERYAN* \\ Department of Natural Sciences, Northwest Missouri State University, Maryville, MO 64468 USA \\ *Corresponding author: khaber@nwmissouri.edu
}

\begin{abstract}
Long-term, integrated records of limnology are rare in the central United States. Mozingo Lake is a reservoir in northwestern Missouri that was sampled regularly since its creation in 1994. Physical data were collected during 121 visits and compared to meteorological observations. July hypolimnetic temperatures have risen rapidly $\left(2.4^{\circ} \mathrm{C} /\right.$ decade: $\left.P=0.037\right)$, suggesting weakened summer stratification in the future. Winter conditions were rarely correlated with lake conditions in the following July; the exception is July epilimnion temperature, which correlated with ice-over date, January hypolimnion temperature, and ice duration $(P=0.006,0.010$, and 0.024). In contrast, winter ice-over date was best correlated with air temperature in the preceding July $(P=0.006)$; other factors were not significantly correlated, including fall air temperatures, July epilimnion temperatures, and October water column temperatures. Analysis of air temperatures preceding ice-over revealed that the strongest correlation was with a 68 -day average air temperature of $4.8^{\circ} \mathrm{C}$. July air temperatures, along with iceover date, correlated with January ice thickness and ice duration ( $P=0.014$ and 0.001 , respectively). This suggests that a warm July is associated with a mild winter, a relationship confirmed by a significant correlation $(P=0.011)$. Ice thickness, ice duration, and ice-out date also correlated with winter air temperature $(P \leq 0.003$ for each). It therefore appears that summer conditions influence winter conditions which, in turn, influence certain lake conditions in the following summer; this observation indicates that winter conditions may not reset physical parameters in lakes. Legacies thus may span various intervals, ranging from a week to a year or more. Although the Mozingo Lake record is brief (20 years), it suggests directions for longer-term studies. Multi-year legacy effects have rarely been documented, but in Mozingo Lake they suggest that a single strong climatic anomaly may affect the lake for several years.
\end{abstract}

Key words: Lake phenology; lake ice; ice-over; ice-out; lake legacies; lake memory.

Received: December 2015. Accepted: February 2016.

\section{INTRODUCTION}

Lakes are complex systems. Geological forces affect lake formation and morphology; these affect the hydrology and annual physics of the lake. These parameters also vary over time, from the annual stratification cycle to longerterm trends that span years. The purpose of this study is to expand limnological knowledge in a poorly-represented region, and especially to quantify the relationship between meteorology and limnological conditions such as summer lake temperatures and winter ice phenomena.

The primary driver of lake-ice parameters is air temperature, although roles are also played by other factors such as cloud cover, snowfall, rainfall, relative humidity, and wind speed (Blenckner et al., 2007; Livingstone and Adrian, 2009). For example, air temperatures in November and December were strong influences of ice-over date in Lake Baikal, moderated somewhat by dynamic factors that may locally (Kouraev et al., 2007). Ice thickness showed a memory effect (i.e., a time lag) of ice-over date and winter conditions. Ice-out depended on mean air temperature in February and in April (Livingstone, 1999), but Todd and Mackay (2003) concluded that snow cover, wind, and river flow were more important than spring air temperatures.
Ice phenology has also been studied in smaller lakes, especially in the temperate parts of Europe and North America. In a German lake, ice cover was closely predicted by an air-temperature probability function (Livingstone, 2009); in 196 Swedish lakes, a nonlinear relationship has been found between ice-out and air temperatures over 1-3 months (Weyhenmeyer et al., 2004). In most areas, ice phenology also responds to longer-term climate variations, including ENSO and NAO (Blenckner et al., 2007; Ghanbari et al., 2009; Patterson and Swindles, 2015); furthermore, ice records often predate air temperature records and thus document climate warming over the time scale of centuries (Korhonen, 2006; Adrian et al., 2009; Benson et al., 2011).

Legacies in lakes are poorly documented. Also called time lags and lake memory, these are phenomena that influence future conditions (Martin et al., 2011; Kouraev et $a l ., 2007)$. Limnological lore suggests that winter air temperatures are related to hypolimnion temperatures in the following summer. However, in four Swiss lakes, deepwater temperature in summer was related to lake temperature at turnover (i.e., displayed a lag of several months), influenced by lake-specific characteristics (Livingstone, 
1993); a relationship with turnover temperature was confirmed by Arvola et al. (2010). In Lake Constance, a oneyear time lag occurred between the NAO and deepwater temperature (Straile et al., 2003).

Mozingo Lake, sometimes mislabeled Hayden Lake, is a reservoir in Nodaway County in northwestern Missouri $\left(40.45^{\circ} \mathrm{N}, 94.78^{\circ} \mathrm{W}\right.$; Fig. 1) which was impounded in 1994. The area was last glaciated sometime prior to 200,000 years ago, leaving a series of valleys that trend north-south (Rovey and Balco, 2011). Floodplains in the area may be a few kilometers wide, and are usually deeply incised (2-3 $\mathrm{m}$ or more) by the primary stream. The total watershed of the lake is about 4955 ha, but precipitation on about 1395 ha of this is intercepted by ponds with little to no annual discharge. Inputs to the lake are precipitation on the lake surface (34\% of the inputs) and runoff from the watershed (66\%), while the losses include evaporation from the surface $(70 \%)$ and withdrawal for human consumption $(30 \%)$. The lake is $6.7 \mathrm{~km}$ long and $15 \mathrm{~m}$ deep, with a volume of about $22 \times 10^{6} \mathrm{~m}^{3}$ (Fig. 1) (Haberyan, unpublished).

\section{METHODS}

Mozingo Lake was sampled 121 times from 1994 to 2014, generally from a mid-lake station (Station 1 in Fig. 1) over the former floodplain (12 m deep), about 330 $\mathrm{m}$ north of the dam and $30 \mathrm{~m}$ east of the drowned stream channel $\left(40.3514^{\circ} \mathrm{N}, 94.774^{\circ} \mathrm{W}\right)$. An alternate location (Station 2) was used during inclement conditions (e.g., storms and thin ice), when sampling took place at a floating dock (depth $3 \mathrm{~m}$ ), located $630 \mathrm{~m}$ to the north-northwest of the mid-lake station. The lake was sampled near the middle of the month (26-37 days apart) from October 1994 through October 1998 and again from April 2010 to April 2011; otherwise, sampling was quarterly (84-97 days apart). Visits were also made every 1-4 days to document the timing of ice-over and ice-out, cued by the status of ice in local farm ponds.

To detect the thermocline, temperature was measured with YSI thermometers (Models 51B and 52CE) at intervals of $1.0 \mathrm{~m}$ throughout, and at $0.5 \mathrm{~m}$ intervals in the vicinity of the thermocline. The temperature of the epilimnion was taken to be that at $1.0 \mathrm{~m}$ depth; for the hypolimnion, it was the penultimate measurement (1.0 to $2.0 \mathrm{~m}$ above the bottom). The temperature of the water column was the average of direct measurements, supplemented by interpolation for each half meter where needed. Daily quality-controlled meteorological data were downloaded for August 1994 through October 2014 from NOAA (Menne et al., 2014) for the Maryville 2E station, located $4.6 \mathrm{~km}$ due west of the mid-lake sampling station at an elevation of $300.2 \mathrm{~m}$ asl. For temperature, each day's maximum and minimum temperatures were averaged; for the 157 days that lacked at least one of these, the average of the bracket- ing dates was substituted. To generate a smooth curve for typical daily lake temperatures, a sine curve was fit to the observed data with iterations continuing until the sum of squared errors was minimal and each term included at least four significant digits. For consistency, this method was also applied to the average air temperatures for each day from October 13, 1994 through October 16, 2014. Relationships among twenty-two physical parameters were explored, based on data collected after the lake first reached overflow in 1996, using two-tailed Pearson bivariate correlation in SPSS v.22; parameters included ice data, air temperatures, and lake conditions. Significant $(\mathrm{P} \leq 0.05)$ Pearson correlations were explored further using curve estimation and

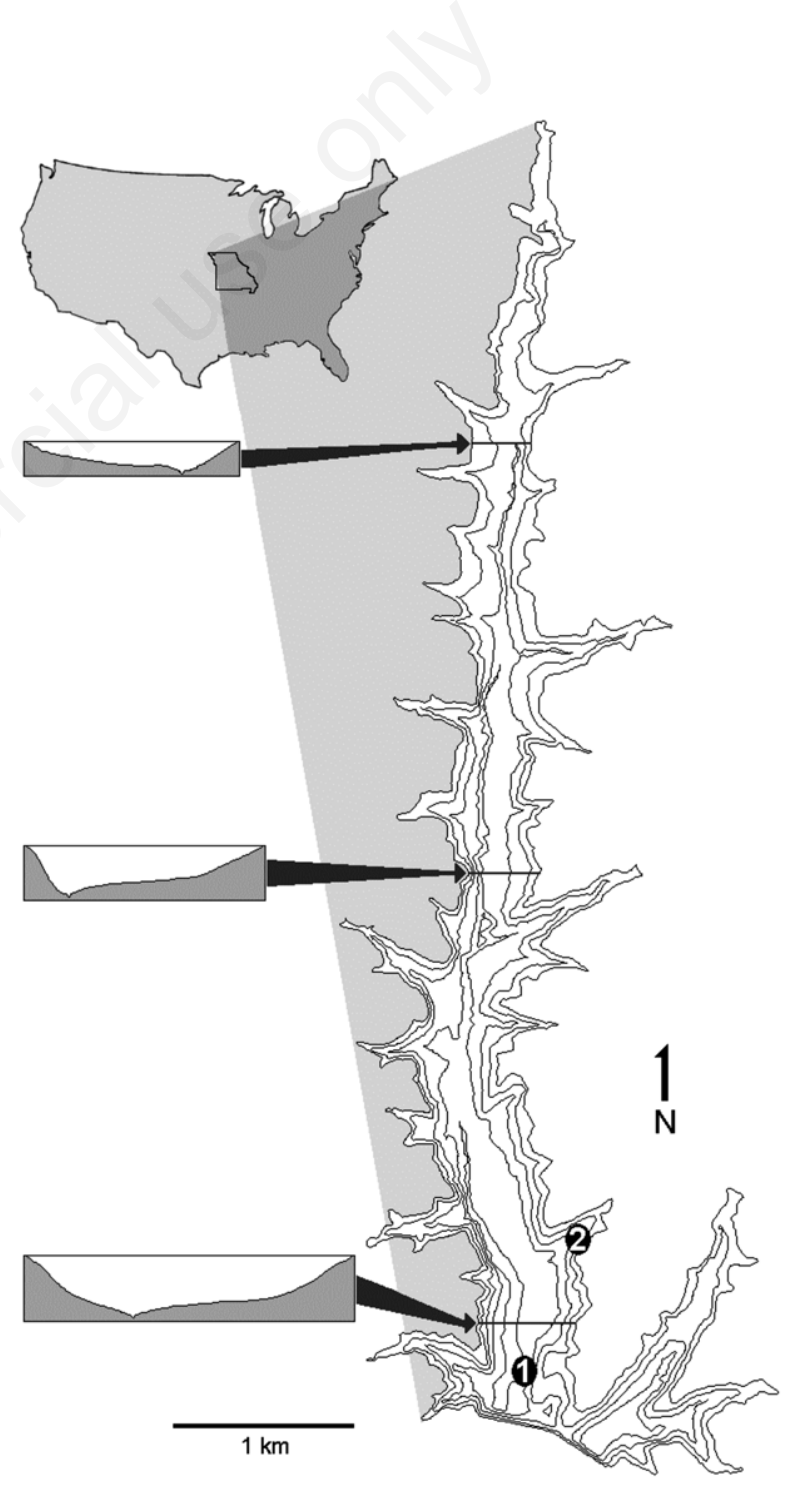

Fig. 1. Contour map of the lake; contour interval $3 \mathrm{~m}$. Stations 1 (primary, southern) and 2 (alternate, central) are shown near the south end of the lake. Vertical exaggeration of transverse profiles is $3.7 \mathrm{x}$. 
multiple linear regressions with forward selection, in order to relate initial conditions (as potential drivers or independent variables) to later conditions (as potential responses or dependent variables). Pearson correlations were also used to explore the role of air temperatures in the timing of subsequent ice-over and ice-out events. For this analysis, daily air temperatures were averaged for varying time intervals preceding ice-over and iceout; 45 time intervals were analyzed in 2-day increments ranging from 2-90 days.

\section{RESULTS}

\section{Basic limnology}

The lake began filling in August of 1994, but for the first few months occupied little more than the incised channel. The greatest monthly rises took place in spring 1995 (4.2 $\mathrm{m})$ and in spring 1996 (2.6 m), so that the lake first overflowed in early June 1996. Since then, the lake level tended to rise in the spring and decline in late summer, except in years of drought (e.g., 2001-2004 and 2012-2014).

The typical annual cycle of the lake has been consistent since reaching overflow (Fig. 2). The lake freezes over every year with an average of $16 \mathrm{~cm}$ of ice overlying a temperature gradient that is usually less than $0.5^{\circ} \mathrm{C} \mathrm{m}^{-1}$ centered between $0.5 \mathrm{~m}$ and $1.0 \mathrm{~m}$ depth. As soon as the ice breaks up, typically in early March, the lake begins mixing until early May. The summer thermocline begins weak and shallow, deepening to 8-9 m by September. Progressive cooling of the surface waters creates near-isothermal temperatures through September, and winds cause complete turnover by
mid-October. Since first overflow, the median date of iceover has been December 23, but this date has varied between December 8 and January 15. Except in April, the temperature of the epilimnion was often slightly greater than the average air temperature (Fig. 3). In July, the epilimnion was typically $0.4^{\circ} \mathrm{C}$ warmer than the average air temperature, and the maximum epilimnion temperature lagged average air temperature by about a month. A similar lag was observed in winter, when the epilimnion was typically $2-3^{\circ} \mathrm{C}$ warmer than the average air temperature. In April, the thermal inertia of water caused it to warm more slowly than does air temperature, with a lag of about 1-2 weeks; a similar lag was observed in the fall. In comparison, the temperature of the entire water column displayed a prolonged lag in the spring (i.e., from April through June). The temperature of the hypolimnion was less clearly related to air temperature and tended to peak in late August.

\section{Predicting summer conditions}

July epilimnion temperature correlated most strongly with ice-over date $(\mathrm{P}=0.006)$ in the previous winter (Tab. 1), but neither July water temperature correlated significantly with lake temperatures during turnover in midApril ( $\mathrm{P}=0.132$ and 0.443 , respectively). Curve estimation revealed that July epilimnion temperature was significantly modeled by January hypolimnion temperature, by ice-over date, and by ice duration (each $\mathrm{P} \leq 0.024$; Tab. 2). Multiple linear regression identified only ice-over date and January hypolimnion temperature as variables that contribute significantly to July hypolimnion temperature $(\mathrm{P}=0.001)$; ice du-
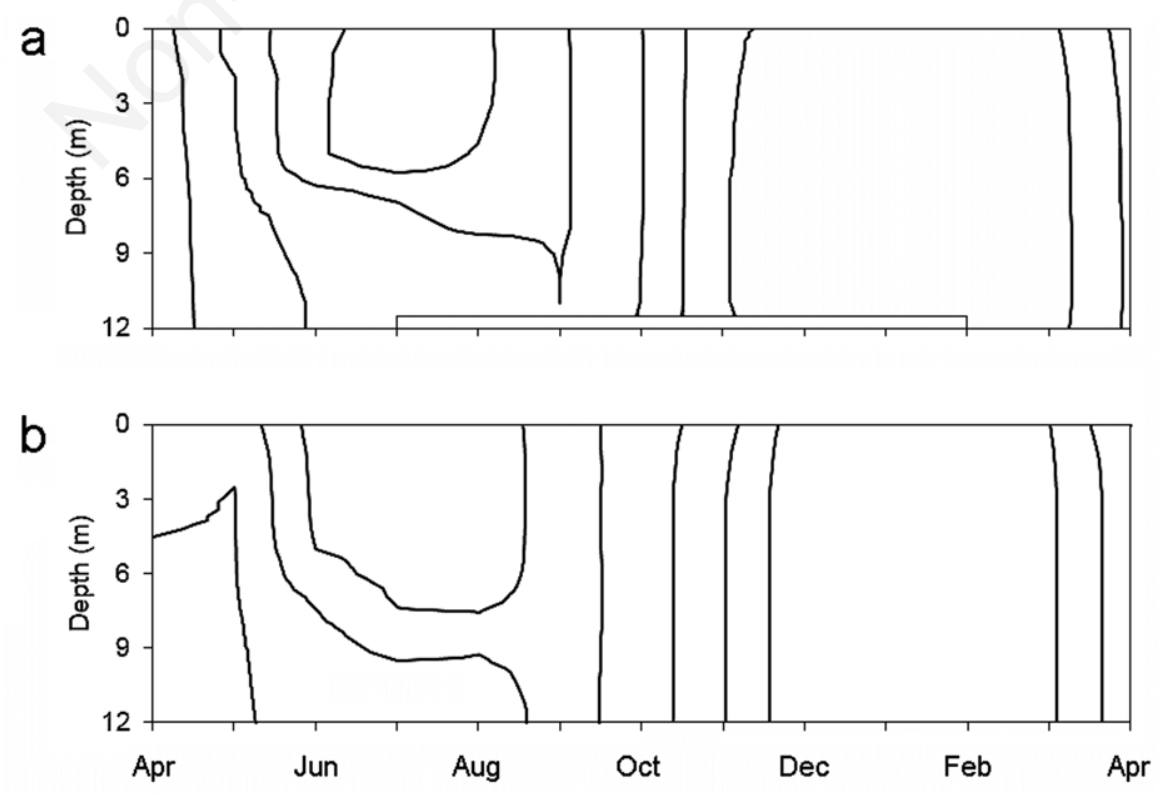

Fig. 2. Thermal structure of the filled lake during two years of monthly sampling. a) April 1997-April 1998. b) April 2010 -April 2011. 
ration did not improve the correlation because it co-varies with ice-over date, and thus duplicates its contribution.

The temperature of the hypolimnion in July has been increasing significantly (slope $2.4^{\circ} \mathrm{C} /$ decade; $\mathrm{P}=0.0373$, $\mathrm{r}^{2}=0.335$ ), but the epilimnetic temperature has not (slope $-0.45^{\circ} \mathrm{C} /$ decade; $\left.\mathrm{P}=0.200, \mathrm{r}^{2}=0.0393\right)$. Winter water mass temperatures have also remained steady $(\mathrm{P}=0.063$ for epilimnion, $\mathrm{P}=0.341$ for hypolimnion).

\section{Predicting winter conditions}

Few winter variables were related to conditions in the preceding summer (Tab. 3); however, July air temperatures correlated positively with air temperatures in the following winter $(\mathrm{P}=0.011)$, but not with October water temperatures (P 0.116). Interestingly, October water temperatures did not correlate with any ice phenomenon (all $\mathrm{P}>0.06$ ). July air temperatures, however, did correlate with each of the ice variables $(\mathrm{P} \leq 0.014)$; the sign of these correlations shows that warmer July air temperatures re-

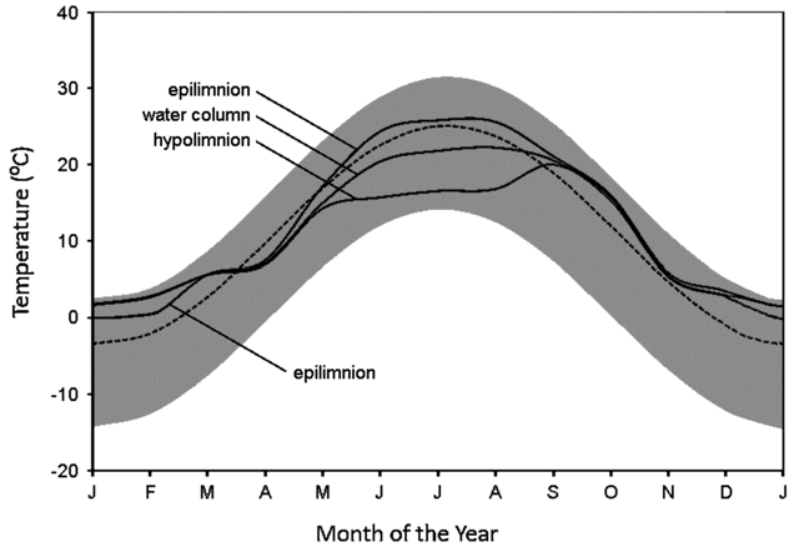

Fig. 3. Typical annual temperatures since overflow. Tick marks on the horizontal axis represent the middle of each month. The shaded area represents the daily air temperature range; dotted line represents average daily air temperature.

Tab. 1. Pearson correlations between winter conditions and July lake temperatures in the following summer. Winter is December, January, and February.

\begin{tabular}{|c|c|c|c|}
\hline Potential drivers & Poi & ntial responses (dependent varia & les) \\
\hline (independent variables) & Jy epilimnion temperature & July hypolimnion temperature & July average water column temperature \\
\hline January air temperature & 0.243 & 0.031 & 0.210 \\
\hline February air temperature & 0.338 & -0.012 & 0.214 \\
\hline Winter air temperature & 0.365 & -0.005 & 0.211 \\
\hline January hypolimnion temperature & $-0.562 * *$ & 0.176 & -0.163 \\
\hline Ice thickness & -0.408 & -0.201 & -0.379 \\
\hline Ice-over date & $0.596 * *$ & 0.299 & $0.473 *$ \\
\hline Ice duration & $-0.503 *$ & -0.057 & -0.284 \\
\hline April average water column temperature & 0.349 & 0.182 & 0.338 \\
\hline
\end{tabular}

$* P<0.05 ; * * P<0.01$.

Tab. 2. Models with the greatest significance levels that relate winter conditions to epilimnion temperatures in the following July $\left(\mathrm{T}_{7 \mathrm{e}}\right)$. Values have been rounded to three figures; coefficients are standardized.

\begin{tabular}{|c|c|c|c|}
\hline Model & $r^{2}$ & $\mathbf{P}$ & \\
\hline $\mathrm{T}_{7 \mathrm{e}}=24.3+5.14 / \mathrm{T}_{1 \mathrm{~h}}$ & 0.380 & $\begin{array}{l}0.004 \\
0.004 \\
0.000\end{array}$ & $\begin{array}{c}\text { for equation } \\
\text { for constant } \\
\text { for coefficient of } \mathrm{T}_{\mathrm{lh}}\end{array}$ \\
\hline $\mathrm{T}_{7 \mathrm{e}}=25.5+0.053 \mathrm{~F}$ & 0.355 & $\begin{array}{l}0.006 \\
0.006 \\
0.000\end{array}$ & $\begin{array}{c}\text { for equation } \\
\text { for constant } \\
\text { for coefficient of } \mathrm{F}\end{array}$ \\
\hline $\mathrm{T}_{7 \mathrm{e}}=27.7+0.046 \mathrm{~F}-0.858 \mathrm{~T}_{1 \mathrm{~h}}$ & 0.573 & $\begin{array}{l}0.003 \\
0.000 \\
0.005 \\
0.009\end{array}$ & $\begin{array}{l}\text { for equation } \\
\text { for constant } \\
\text { for coefficient of } \mathrm{F} \\
\text { for coefficient of } \mathrm{T}_{1 \mathrm{~h}}\end{array}$ \\
\hline
\end{tabular}

$T_{I h}$, January hypolimnion temperature; $F$, ice-over date; $D$, ice duration. 
sult in later ice-over, thinner ice, and reduced ice duration. In subsequent curve estimations, each of the ten models was significantly related to July air temperature; the best fit of these were the exponential models for ice-over date and for ice thickness, and the linear model for ice duration $(\mathrm{P} \leq 0.012 ;$ Tab. 4). Multiple linear regression revealed that only July air temperature was significantly related; other variables did not improve model significance.
Correlations between average air temperatures and ice phenomena were chaotic within 44 days of ice-over, but longer-term temperature averages were significantly correlated (Fig. 4). Ice-over date was significantly correlated with average air temperatures for periods longer than 44 days (Tab. 4), corresponding with an average air temperature of $2.1^{\circ} \mathrm{C}$. Ice thickness was significantly related only to the 70- and 72-day average air temperatures (about

Tab. 3. Pearson correlations between summer conditions and ice variables in the following winter. Summer is June, July, and August; winter is December, January, and February. January, February, and winter air temperatures were concurrent with the ice parameters of that year.

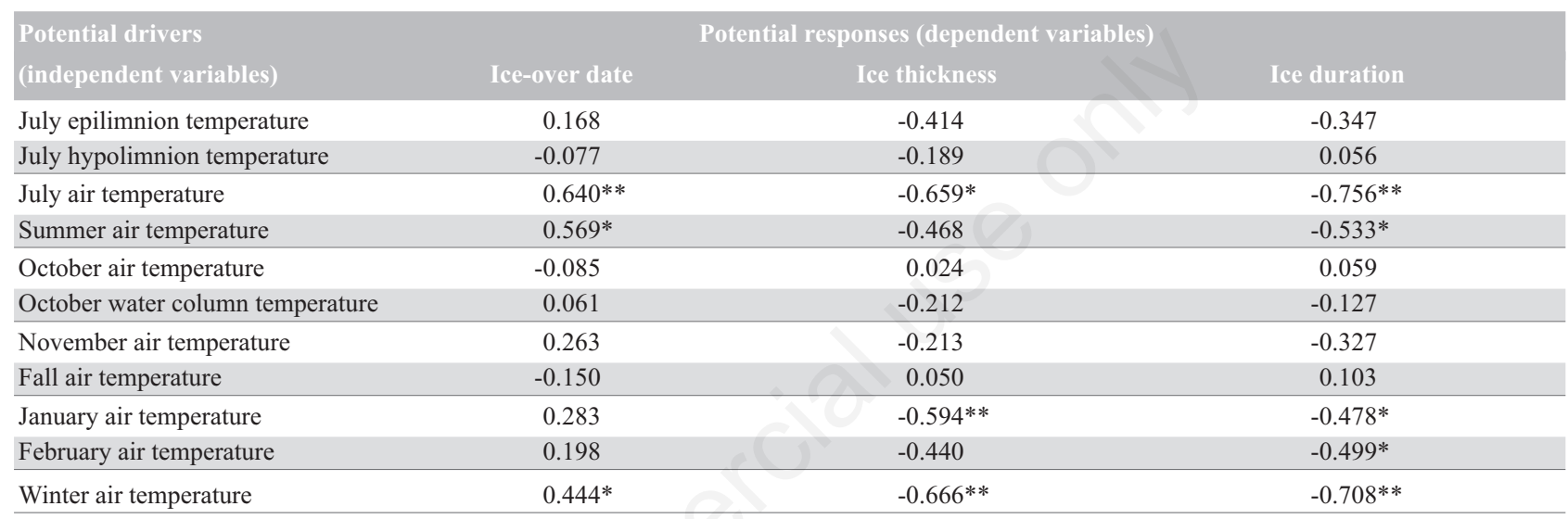

$* P<0.05 ; * * P<0.01$.
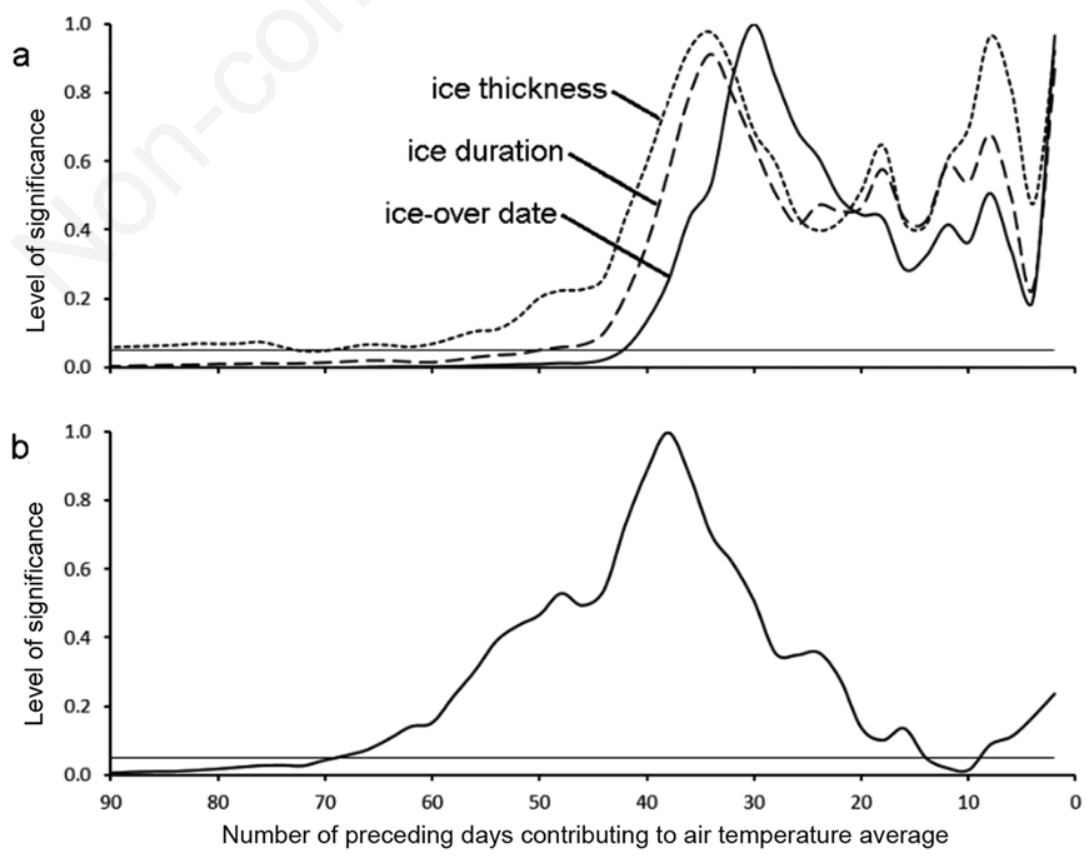

Fig. 4. Significance levels of Pearson correlations for air temperature averaged over various time periods. a) Winter ice phenomena related to temperatures preceding ice-over. b) Ice-out date related to temperatures preceding ice-out. Solid horizontal line represents a significance level of 0.05 . 
$5.3^{\circ} \mathrm{C}$ ). Ice duration was significantly related to a 50 -day average air temperature of $2.9^{\circ} \mathrm{C}$. Similarly, ice-out was significantly related to average winter temperature, to the 10-day average air temperature of $0.4{ }^{\circ} \mathrm{C}$, and to ice thickness $(\mathrm{P}=0.000,0.005$, and 0.014 , respectively).

Winter conditions also correlated with each ice variable; correlation was especially strong with average winter air temperatures (i.e., December-January-February), suggesting that severe winters often start early (correlation with ice-over date, $\mathrm{P}=0.050$ ), cause increased ice thickness $(\mathrm{P}=0.003)$, cause longer ice duration $(\mathrm{P}=0.000)$, and cause delayed ice-out $(\mathrm{P}=0.000)$.

\section{DISCUSSION}

\section{Basic limnology}

The annual cycle of stratification was evident in lake temperatures. The temperature curves in spring were not mirrored in the fall (Fig. 3); rather, the epilimnion began to cool in late August, but the hypolimnion continued to warm until mid-September. This occurred because warmer surface waters continue to mix into the cooler deep waters well into September. Recent studies have broadly linked epilimnion temperature to air temperature, and indicated a role for lake depth (i.e., thermal inertia: Toffolon et al., 2014).

\section{Predicting summer conditions}

Summer hypolimnion temperature is often thought to reflect air temperature in the previous winter, but data from Mozingo Lake do not support this relationship. No correlation was found between hypolimnion temperature and ice duration nor with ice-over date, perhaps partly due to the brief period of observation, and additional data are needed to clarify these influences. Other studies have found that summer hypolimnion temperature does correlate with lake temperature during turnover in large Swiss lakes (Arvola et al., 2010; Livingstone, 1993), but this relationship was not significant for Mozingo Lake ( $\mathrm{P}>0.13)$. This difference is likely due to the much smaller size of Mozingo Lake; in the larger Swiss lakes, deep water tracks longer-term trends (Livingstone, 1993). In Mozingo, water temperatures in general reflect seasonal temperatures more closely, and spring turnover is much shorter (about 6 weeks) than in the Swiss lakes. Consequently, summer water temperatures in Mozingo are less affected by air temperatures during turnover. In addition to size and depth, Mozingo Lake differs from the Swiss lakes in climate, river inputs, and stability of stratification (Livingstone, 1993).

In contrast, linear models did predict July epilimnion temperatures based on ice-over date and January hypolimnion temperature (Tab. 5). An early ice-over date also correlates with a harsh winter $(\mathrm{P}=0.011)$, and provides ample time to chill the lake; this chill may persist through the brief spring turnover. Alternatively, these correlations may have resulted from the relative brevity of the record (18 years).

\section{Predicting winter conditions}

The most important predictor of ice conditions was air temperature in the previous July; in fact, although other temperatures were individually correlated, none improved the multiple linear regression significantly. The effects of July air temperatures were logical, that is, warm July air temperature correlates with delayed ice-over, thinner ice, and shorter ice duration. However, the mechanism does not seem to involve water as a heat carrier, because October water temperatures did not correlate with either July air temperature $(\mathrm{P}=0.116)$ or with any of the ice parameters (ice-over, ice thickness, ice-out; $\mathrm{P}>0.06$ for each). Rather, the significant correlation between July air temperatures and air temperatures in the following winter $(\mathrm{P}=0.011)$ sug-

Tab. 4. Models with the greatest significance levels that relate July air temperatures to ice conditions in the following winter. Values have been rounded to three figures.

\begin{tabular}{|c|c|c|c|c|}
\hline Potential response (dependent variable) & Model & $r^{2}$ & $\mathbf{P}$ & \\
\hline Ice-over date & $\mathrm{F}=0.035 \mathrm{e}^{0.253 \mathrm{~J}}$ & 0.445 & $\begin{array}{l}0.003 \\
0.591 \\
0.003\end{array}$ & $\begin{array}{l}\text { for equation } \\
\text { for coefficient of } e \\
\text { for coefficient of } J\end{array}$ \\
\hline Ice thickness & $\mathrm{L}=0.687 \mathrm{e}^{0.012 \mathrm{~J}}$ & 0.452 & $\begin{array}{l}0.012 \\
0.687 \\
0.012\end{array}$ & $\begin{array}{l}\text { for equation } \\
\text { for coefficient of } \mathrm{e} \\
\text { of coefficient of } \mathrm{J}\end{array}$ \\
\hline Ice duration & $\mathrm{D}=326-10.2 \mathrm{~J}$ & 0.572 & $\begin{array}{l}0.001 \\
0.000 \\
0.001\end{array}$ & $\begin{array}{l}\text { for equation } \\
\text { for constant } \\
\text { for coefficient of } J\end{array}$ \\
\hline Ice-out date & $\mathrm{M}=49.4-4.34 \mathrm{~T}_{\mathrm{W}}$ & 0.683 & $\begin{array}{l}0.000 \\
0.000 \\
0.000\end{array}$ & $\begin{array}{l}\text { for equation } \\
\text { for constant } \\
\text { for coefficient of } T_{w}\end{array}$ \\
\hline
\end{tabular}

$J$, average July air temperature; $F$, ice-over date; $L$, ice thickness; $D$, ice duration; $M$, ice-out date; $T_{\text {W }}$ average winter air temperature (December-January-February). 
gests that unusually warm summers predict mild winters. Ice-over was most likely to occur when the 68-day average air temperature was $4.8^{\circ} \mathrm{C}$. Previous studies have confirmed that ice-over is more difficult to predict than ice-out, due to the various heat exchange processes, wind strength, humidity, cloud cover, and lake mixing depth (Šporka et al., 2006; Adrian et al., 2009; Livingstone and Adrian, 2009). In addition, fall weather here is notoriously chaotic.

In turn, ice-over date was a good predictor of ice thickness and of ice duration, exactly confirming the findings of Korhonen (2006). Once the ice is in place, its thickness and duration also correlate strongly with concurrent winter air temperatures $(\mathrm{P} \leq 0.003)$, as observed by others (Korhonen, 2006; Livingstone and Adrian, 2009); thus both winter temperatures and ice-over dates affect ice thickness and duration, as in Lake Baikal (Kouraev et al., 2007).

Ice-out is primarily related to processes internal to the lake, and thus predictions are often more reliable (Korhonen, 2006; Adrian et al., 2009); additional roles have been described for precipitation, cloud cover, and wind speed (Nõges and Nõges, 2014). In Mozingo Lake, ice-out was well predicted based on winter air temperatures (Tab. 5), but the linear model was only slightly better than curvilinear ones. In comparison, an extensive study of 196 Swiss lakes over 30 years found a nonlinear relationship between ice-out and mean annual temperature (Weyhenmeyer et al., 2004). In addition, the Mozingo Lake record is rather brief, and many more years of study will be required to distinguish a linear trend from a nonlinear one.

\section{Climate change and lake conditions}

Despite the brevity of the record, one significant climate-related trend has been detected in Mozingo Lake. The hypolimnetic temperature in July has risen by $2.4^{\circ} \mathrm{C} /$ decade $(\mathrm{P}=0.037)$, which is over twice the rate generally reported for near-surface lake temperatures elsewhere (Nõges and Nõges, 2014, and references therein). Since the July epilimnetic temperatures have not changed significantly $(\mathrm{P}=0.200)$, summer stratification has become weaker, in contrast to its strengthening as reported or pre- dicted elsewhere (Adrian et al., 2009, and references therein). Weakened and shortened stratification in Mozingo should ultimately increase phytoplankton productivity overall but reduce cyanobacteria; indeed, a strong decline in cyanobacteria began in 2009 , but this may reflect trophic changes instead.

These Mozingo Lake models relate ice parameters to air temperature, and so may be used to predict changes due to global warming. The most recent IPCC (2014) predictions for low-to-moderate warming (IPCC Scenario RCP4.5) suggest that a $1.7^{\circ} \mathrm{C}$ warming is likely by 2100 . While predictions so far in the future must be viewed with caution (Nõges and Nõges, 2014), the models suggest that, in the year 2100, Mozingo Lake will typically freeze over 18 days later than was typical from 1996-2014. In addition, mid-January ice thickness will have declined by $3.4 \mathrm{~cm}$ (to $16.2 \mathrm{~cm}$ ), and ice duration will decline dramatically, from 68 days currently to 58 days in 2100 . Not surprisingly, these predictions indicate that ice cover will continue its historical decline (Korhonen, 2006; Adrian et al., 2009; Ghanbari et al., 2009; Livingstone and Adrian, 2009; Benson et al., 2011).

\section{CONCLUSIONS}

In Mozingo Lake, July air temperature drives ice-over, which in turn drives ice thickness and ice duration. Ice duration influences epilimnion temperature in the following July. Thus July air temperature in one year influences ice conditions in the following, which then influence epilimnion temperatures in the following July. This three-part sequence forms a one-year time lag between air conditions and lake temperatures. Mozingo Lake exhibits legacies on several time scales, ranging from 1 week (lake temperature lags air temperature in fall and spring) to 1 month (maximum epilimnion temperature lags maximum air temperature in late summer), to 5 months or more (iceover, ice thickness, and ice duration lag July air temperatures). Thus, not only do lakes show legacy effects from season to season, they may also show legacies from year to year, and from one medium to another (e.g., air to ice

Tab. 5. Pearson correlations between ice conditions and recent air temperatures. Note that temperatures preceding ice-over correlated with ice-over date, ice thickness, and ice duration, but ice-out correlated with temperatures preceding ice-out. Significance levels are given in parentheses.

\begin{tabular}{|c|c|c|}
\hline Variable & Minimum significant duration and temperature & Duration and temperature with the strongest correlation \\
\hline Ice-over date & $\begin{array}{c}44 \text { days at } 2.1^{\circ} \mathrm{C} \\
\text { before ice-over }(\mathrm{P}=0.022)\end{array}$ & $\begin{array}{c}68 \text { days at } 4.8^{\circ} \mathrm{C} \\
\text { before ice-over }(\mathrm{P}=0.000)\end{array}$ \\
\hline Ice thickness & $\begin{array}{c}70 \text { days at } 5.0^{\circ} \mathrm{C} \\
\text { before ice-over }(\mathrm{P}=0.046)\end{array}$ & $\begin{array}{c}72 \text { days at } 5.3^{\circ} \mathrm{C} \\
\text { before ice-over }(\mathrm{P}=0.045)\end{array}$ \\
\hline Ice duration & $\begin{array}{c}50 \text { days at } 2.9^{\circ} \mathrm{C} \\
\text { before ice-over }(\mathrm{P}=0.049)\end{array}$ & $\begin{array}{l}90 \text { days at } 7.3^{\circ} \mathrm{C} \\
\text { before ice-over }(\mathrm{P}=0.002)\end{array}$ \\
\hline Ice-out & $\begin{array}{l}10 \text { days at } 0.4^{\circ} \mathrm{C} \\
\text { before ice-out }(\mathrm{P}=0.014)\end{array}$ & $\begin{array}{c}10 \text { days at } 0.4^{\circ} \mathrm{C} \\
\text { before ice-out }(\mathrm{P}=0.014)\end{array}$ \\
\hline
\end{tabular}


to water). Such relationships certainly vary with lake size (Fee and Hecky, 1992) and with the relative roles of external and internal drivers. Predictions can be optimized by using long-term monitoring of the lake of interest (i.e., forecasting) and by sampling other local lakes (i.e., interpolation; Lottig and Carpenter, 2012).

Lakes are therefore complex systems indeed, even regarding purely physical phenomena such as ice-over and ice-out; the relationship between their physical characteristics and weather may not be obvious nor easily modelled. It is clear that, in temperate lakes, seasonal changes drive physical changes in lakes, especially mixing and stratification. As these systems are studied in more holistic ways, with more frequent sampling and over longer time scales, general patterns may well emerge, patterns that increase our ability to predict natural and anthropogenic changes.

\section{ACKNOWLEDGMENTS}

This study was supported by Northwest Missouri State University: field sampling equipment was provided by the Department of Natural Sciences; analytic equipment was provided by the College of Arts and Sciences; and SPSS was provided by Computing Services. The preparation of the manuscript was made possible due to a sabbatical leave that was generously provided by Northwest Missouri State University. I am grateful to the two anonymous reviewers, whose focused efforts improved the clarity and quality of the manuscript dramatically. I also thank the numerous students who assisted in the field.

\section{REFERENCES}

Adrian R, O’Reilly CM, Zagarese H, Baines SB, Hessen DO, Keller W, Livingstone DM, Sommaruga R, Straile D, Van Donk E, Weyhenmeyer GA, Winder M, 2009. Lakes as sentinels of climatic change. Limnol. Oceanogr. 54:2283-2297.

Arvola L, George G, Livingstone DM, Järvinen M, Blenckner T, Dokulil MT, Jennings E, Aonghusa NC, Nõges P, Nõges T, Weyhenmeyer GA, 2010. The impact of changing climate on the thermal characteristics of lakes, p. 85-101. In: D.G. George (ed.), The impact of climate change on European lakes. Aquatic Ecology Series 4. Springer.

Benson BJ, Magnuson JJ, Jensen OP, Card VM, Hodgkins G, Korhonen J, Livingstone DM, Stewart KM, Weyenmeyer GA, Granin NG, 2011. Extreme events, trends, and variability in Northern Hemisphere lake-ice phenology (18552005). Climatic Change 112:299-323.

Blenckner T, Adrian R, Livingstone DM, Jennings E, Weyhenmeyer GA, George DG, Jankowski T, Järvinen M, Aonghusa NC, Nõges T, Straile D, Teubner K, 2007. Large-scale climatic signatures in lakes across Europe: a meta-analysis. Global Change Biol. 13:1314-1326.

Fee EJ, Hecky RE, 1992. Introduction to the northwest Ontario lake size series NOLSS. Can. J. Fish. Aquat. Sci. 49: 2434-2444.

Ghanbari RN, Bravo HR, Magnuson JJ, Hyzer WG, Benson BJ, 2009. Coherence between lake ice cover, local climate and teleconnections (Lake Mendota, Wisconsin). J. Hydrol. 374:282-293.

IPCC, 2014. Climate Change 2014: Synthesis Report, Figure 2.8-01. Contribution of Working Groups I, II and III to the Fifth Assessment Report of the Intergovernmental Panel on Climate Change. IPCC, Geneva.

Korhonen J, 2006. Long-term trends in lake ice cover in Finland, p. 71-78. In: H. Saeki (ed.), Proc. $18^{\text {th }}$ IAHR International Symp. on Ice.

Kouraev AV, Semovski SV, Shimaraev MN, Mognard NM, Legrésy B, Rémy F, 2007. The ice regime of Lake Baikal from historical and satellite data: relationship to air temperature, dynamical and other factors. Limnol. Oceanogr. 42:1268-1286.

Livingstone DM, 1993. Temporal structure in the deep-water temperature of four Swiss lakes: A short-term climatic change indicator? Verh. Internat. Verein. Limnol. 25:75-81.

Livingstone DM, 1999. Ice break-up on southern Lake Baikal and its relationship to local and regional air temperatures in Siberia and the North Atlantic Oscillation. Limnol. Oceanogr. 44:1486-1497.

Livingstone DM, Adrian R, 2009. Modeling the duration of intermittent ice cover on a lake for climate-change studies. Limnol. Oceanogr. 54:1709-1722.

Lottig NR, Carpenter SR, 2012. Interpolating and forecasting characteristics using long-term data. Limnol. Oceanogr. 57:1113-1125.

Martin SL, Hayes DB, Rutledge DT, Hyndman DW, 2011. The land-use legacy effect: adding temporal context to lake chemistry. Limnol. Oceanogr. 56:2362-2370.

Menne MJ, Durre I, Korzeniewski B, McNeal S, Thomas K, Yin X, Anthony S, Ray R, Vose RS, Gleason BE, Houston TG, 2014. Global historical climatology network - daily GHCNDaily, ver. 3.20. NOAA National Climatic Data Center.

Nõges P, Nõges T, 2014. Weak trends in ice phenology of Estonian large lakes despite signficant warming trends. Hydrobiologia 731:5-18.

Patterson RT, Swindles GT, 2015. Influence of ocean-atmospheric oscillations on lake ice phenology in eastern North America. Climate Dynam. 45:2293-2308.

Rovey II CW, Balco G, 2011. Summary of Early and Middle Pleistocene glaciations in northern Missouri, USA, p. 553561. In: J. Ehlers, P.L.Gibbard and P.D. Hughes (eds.), Developments in Quaternary Science. 15. Elsevier.

Šporka F, Livingstone DM, Stuchlík, Turek J, Galas J, 2006. Water temperatures and ice cover in lakes of the Tatra Mountains. Biologia 61:77-90.

Straile D, Jöhnk K, Rossknecht H, 2003. Complex effects of winter warming on the physicochemical characteristics of a deep lake. Limnol. Oceanogr. 48:1432-1438.

Todd MC, Mackay AW, 2003. Large-scale climatic controls on Lake Baikal ice cover. J. Climatol. 19:3186-3199.

Toffolon M, Piccolroaz S, Majone B, Soja A-M, Peeters F, Schmid M, Wüest A, 2014. Prediction of surface temperature in lakes with different morphology using air temperature. Limnol. Oceanogr. 59:2185-2202.

Weyhenmeyer GA, Meili M, Livingstone DM, 2004. Nonlinear temperature response of lake ice breakup. Geophys. Res. Lett. 31:L07203. 